\title{
PEB-COVID-19: Analysis of Students Behavior and ILMIZI Model in Environmental Learning
}

\author{
Ilmi Zajuli Ichsan ${ }^{*}$, Henita Rahmayanti' ${ }^{1}$ Agung Purwanto', Diana Vivanti Sigit ${ }^{1}$ \\ Md. Mehadi Rahman² \\ 1 Universitas Negeri Jakarta, Indonesia \\ 2 University of Dhaka, Bangladesh
}

Corresponding Author: Ilmi Zajuli Ichsan, $@$ ilmizajuli95@gmail.com*

\begin{tabular}{|c|c|}
\hline \multirow[b]{2}{*}{$\begin{array}{l}\text { ARTICLE INFO } \\
\text { Article history: } \\
\text { Received } \\
\text { April 30, } 2020 \\
\text { Revised } \\
\text { May 7, 2020 } \\
\text { Accepted } \\
\text { May 16, } 2020\end{array}$} & ABSTRACT \\
\hline & $\begin{array}{l}\text { Environmental learning during COVID-19 experienced a change to e- } \\
\text { learning. The use of learning models must be compatible; one model that } \\
\text { can be chosen was the ILMIZI model. In addition to learning the concept } \\
\text { of COVID-19, students must also be able to implement it in the form of } \\
\text { Pro-Environmental Behavior (PEB) COVID-19. The purpose of this study } \\
\text { was to analyze descriptively about PEB-COVID-19 and also analyze the } \\
\text { potential of ILMIZI to be applied in e-learning. The research conducted } \\
\text { using a descriptive method. The sample was } 148 \text { Junior High School } \\
\text { students located in Bekasi City and Bandung city. The data was collected } \\
\text { online using Google form. The results showed that the PEB-COVID-19 } \\
\text { student score was already in the very high category. While the results of } \\
\text { the analysis show that the ILMIZI model allows it to be used in e- } \\
\text { learning. This study concluded that the score of PEB-COVID-19 students } \\
\text { was still in the very low category and the use of the ILMIZI model was } \\
\text { one form of learning innovation. }\end{array}$ \\
\hline \multirow[b]{2}{*}{ How to cite } & $\begin{array}{ll}\text { Keywords: } & \text { COVID-19, ILMIZI Model, PEB-COVID-19, Pro-Environmental } \\
& \text { Behavior }\end{array}$ \\
\hline & $\begin{array}{l}\text { Ichsan, I. Z., Rahmayanti, H., Purwanto, A., Sigit, D.V., \& Rahman, M. M. } \\
\text { (2020). PEB-COVID-19: Analysis of Students Behavior and ILMIZI Model in } \\
\text { Environmental Learning. Jurnal Iqra' : Kajian Ilmu Pendidikan, 5(1). 1-11. } \\
\text { https://doi.org/10.25217/ji.v5i1.901 }\end{array}$ \\
\hline Journal Homepage & http://journal.iaimnumetrolampung.ac.id/index.php/ji/ \\
\hline This is an open acces & $\begin{array}{l}\text { article under the CC BY SA license } \\
\text { https:// creativecommons.org/licenses/by-sa/4.0/ } \\
\text { Institut Agama Islam Ma'arif NU (IAIMNU) Metro }\end{array}$ \\
\hline
\end{tabular}

\section{INTRODUCTION}

Environmental problems that arise when the pandemic Corona Virus Disease (COVID-19) requires a problem solution. COVID-19 is a global problem that affects many countries in the world (Tian et al., 2020; Zhou et al., 2020). The rapid spreading rate of COVID-19 has affected every sector of human life including education to students across the world (Sintema, 2020). The problems that arise are related to the lack of education to students about preventing the spread of COVID-19 in the environment. Pro-Environmental Behavior (PEB) is an important thing to prevent environmental damage (Bronfman et al., 2015; Nadlifatin et al., 2016). That is because PEB is an implementation of the knowledge, in this case, PEB in students. Environmental learning in the 21st century when COVID-19 made a change in the learning system to be based on 
electronic learning (e-learning). That makes learning about the environment can change. It also requires adaptation to learning models that can be adaptive to elearning systems.

E-learning is a learning system using online learning media (Al-araibi et al., 2019; Alhawiti \& Abdelhamid, 2017; Mbipom et al., 2018; Mhouti et al., 2018; Teo et al., 2018). That resulted in the learning model used also had to adjust. The use of conventional learning models will indeed be more easily applied to e-learning, but that was not so effective to improve students' competency. However, many teachers did not apply the right learning model, especially in environmental learning during the COVID-19 outbreak. Applying the right learning model will make e-learning have a positive impact on students learning. One model that has the potential to be used in e-learning during COVID-19 is the ILMIZI learning model.

Previous research has been conducted related to the ILMIZI learning model. In general, ILMIZI is a learning model for learning science and technology. The syntax of ILMIZI consists of 6 stages start from Identify problem, Limitation problem, Make mind map, Interpret result, Analyze result, Interaction, and evaluate (Ichsan, 2019). These six syntaxes have the potential to be used in environmental learning of the 21st century and are compatible with e-learning systems. Previous research that has been done related to the implementation of ILMIZI showed that for the elementary school level, the ILMIZI model can improve student knowledge (Ichsan et al., 2020).

Knowledge during e-learning must be able to implement in contextual daily life (Kartikaningtyas et al., 2018; Paristiowati et al., 2019; Voight et al., 2014). The present research was essential to do, because the topic of contextual environmental learning was in the context of PEB to prevent COVID-19. PEB specifically focuses on COVID-19, called PEB-COVID-19. Measurement of PEBCOVID-19 becomes important because to make more accurate measurements of environmental behavior in the context of COVID-19, it needs to be measured with a special instrument namely PEB-COVID-19. This research is an urgent thing to do and has a novelty that is related to the description of PEB-COVID-19 students, in this case, the junior high school level. That's because students at this level will be more susceptible to COVID-19 Pandemic. Based on the description, the purpose of this study was to analyze descriptively about PEB COVID-19 and also analyzed the use of ILMIZI when an e-learning system occurs during an outbreak of COVID-19.

\section{METHODS}

This research was conducted in a descriptive method using survey techniques. The study was conducted in March 2020 during the COVID-19 pandemic in Indonesia. The sample used in this study was Junior High School students from Bekasi City and Bandung City, West Java Province. The number of samples involved in this study was 148 students consisting of 59 male students and 89 female students. The instrument of this study was PEB-COVID- 
19 whose indicators were adapted from Kaiser \& Wilson (2004). There are 3 indicators used to measure PEB-COVID-19 which can be seen in Table 1.

Table 1. PEB-COVID-19 Instrument Indicators

\begin{tabular}{lll}
\hline No & Indicator & Item \\
\hline 1 & Clean the home and environment to prevent COVID-19 & $1,2,3$ \\
2 & Avoid visiting places with a dirty environment because of COVID-19 & $4,5,6$ \\
3 & $\begin{array}{l}\text { Reducing interactions with various objects that have the potential to } \\
\text { transmit COVID-19 in the environment }\end{array}$ & $7,8,9,10$ \\
\hline
\end{tabular}

The instrument was distributed using Google forms through online media. The validity and reliability test results showed that the PEB COVID-19 instrument was valid and reliable for use in this study. Analysis of the data used is descriptively by analyzing in tabular form. The analysis results are then interpreted according to the PEB COVID-19 category in Table 2 below.

Table 2. PEB-COVID-19 Score Categories

\begin{tabular}{ll}
\hline Categories & Interval Score \\
\hline Very High & $\mathrm{X}>81,28$ \\
High & $70,64<\mathrm{X} \leq 81,28$ \\
Moderate & $49,36<\mathrm{X} \leq 70,64$ \\
Low & $38,72<\mathrm{X} \leq 49,36$ \\
Very Low & $\mathrm{X} \leq 38,72$ \\
\hline
\end{tabular}

Source: Adapting categories from Sigit et al. (2020)

Besides doing a descriptive analysis of PEB-COVID-19, this study also analyzed the potential of the ILMIZI model to be used in environmental elearning. That is because the ILMIZI model is a newly developed model consisting of 6 stages namely Identify a problem, Limitation problem, Make mind map, Interpret result, Analyze Result, Interaction, and evaluate (Ichsan, 2019). The ILMIZI model has also been implemented in the class, but it has not yet been done for e-learning systems. This research will be analyzed in the ILMIZI model at environmental e-learning.

\section{RESULT AND DISCUSSION}

The results showed that the overall score of PEB-COVID-19 was very high. This indicates that the behavior of students to prevent the spread of COVID-19 is already very high. However, in some instrument items, scores were found to still have the lowest scores. All students and female students showed the lowest score was related to the habit of shaking hands. In contrast to the male students in the aspect of avoiding various metal objects, more details can be seen in Table 3. 
Table 3. PEB-COVID-19 Junior High School Student Scores

\begin{tabular}{|c|c|c|c|c|}
\hline No & Item & $\begin{array}{l}\text { All } \\
(n=148)\end{array}$ & $\begin{array}{l}\text { Male } \\
(\mathrm{n}=59)\end{array}$ & $\begin{array}{l}\text { Female } \\
(\mathbf{n}=89)\end{array}$ \\
\hline 1 & $\begin{array}{l}\text { The floor at home is cleaned with anti-bacterial } \\
\text { fluids to avoid a variety of bacteria and viruses, } \\
\text { including COVID-19 }\end{array}$ & 4.39 & 4.42 & 4.36 \\
\hline 2 & $\begin{array}{l}\text { Garbage in the house is thrown into the right place } \\
\text { to avoid the spread of COVID-19 }\end{array}$ & 4.70 & 4.71 & 4.70 \\
\hline 3 & $\begin{array}{l}\text { Air circulation in the house is kept clean so that } \\
\text { health is maintained to prevent a decrease in body } \\
\text { immunity to prevent COVID-19 }\end{array}$ & 4.42 & 4.36 & 4.46 \\
\hline 4 & $\begin{array}{l}\text { I avoid going to public places with the potential to } \\
\text { transmit COVID-19 }\end{array}$ & 4.45 & 4.36 & 4.51 \\
\hline 5 & $\begin{array}{l}\text { I avoid visiting places with dirty environmental } \\
\text { conditions to prevent COVID-19 }\end{array}$ & 4.62 & 4.44 & 4.74 \\
\hline 6 & $\begin{array}{l}\text { I minimize travel to a densely populated } \\
\text { neighborhood or to the crowd to avoid COVID-19 }\end{array}$ & 4.49 & 4.47 & 4.49 \\
\hline 7 & $\begin{array}{l}\text { I avoid touching equipment such as elevator } \\
\text { buttons, banknotes, and other media that have the } \\
\text { potential to transmit COVID-19 }\end{array}$ & 3.98 & 3.78 & 4.11 \\
\hline 8 & $\begin{array}{l}\text { I washed my hands after touching metal objects in } \\
\text { public places, to avoid COVID-19 }\end{array}$ & 4.37 & 4.39 & 4.36 \\
\hline 9 & $\begin{array}{l}\text { I shook hands without touching to reduce the } \\
\text { impact of COVID-19 }\end{array}$ & 3.89 & 3.81 & 3.93 \\
\hline 10 & $\begin{array}{l}\text { I will dispose of trash, after that wash my hands } \\
\text { immediately to avoid the spread of COVID- } 19\end{array}$ & 4.41 & 4.41 & 4.42 \\
\hline \multicolumn{2}{|c|}{ Raw Score } & 43.72 & 43.15 & 44.08 \\
\hline \multicolumn{2}{|c|}{ Average Score (scale 0-100) } & 87.44 & 86.30 & 88.16 \\
\hline \multirow{2}{*}{\multicolumn{2}{|c|}{ Category }} & Very & Very & Very \\
\hline & & High & High & High \\
\hline
\end{tabular}

Note: each item have interval score 1-5

The results of the study following the indicators showed that the lowest indicator related to reducing interactions with various objects that have the potential to transmit COVID-19. This showed that there are still many students who have not maintained the sanitation and cleanliness of their hands and various other objects. More details about the score can be seen in Table 4 .

Table 4. The average PEB-COVID-19 Score based on each Indicator

\begin{tabular}{lllll}
\hline No & Indicator & All & Male & Female \\
\hline 1 & $\begin{array}{l}\text { Clean the home and environment to prevent } \\
\text { COVID-19 }\end{array}$ & 4.50 & 4.50 & 4.51 \\
2 & $\begin{array}{l}\text { Avoid visiting places with a dirty environment } \\
\text { because of COVID-19 }\end{array}$ & 4.52 & 4.42 & 4.58 \\
3 & $\begin{array}{l}\text { Reducing interactions with various objects that } \\
\text { have the potential to transmit COVID-19 in the } \\
\text { environment }\end{array}$ & 4.16 & 4.10 & 4.21 \\
\hline
\end{tabular}


The next analysis is about using the ILMIZI model in environmental learning during COVID-19 to empower PEB-COVID-19. The results of the analysis showed that the ILMIZI model is suitable to be used in e-learning. Modifications are made to teacher activity and student activity, while for syntax it cannot be modified because it is permanent (Ichsan et al., 2020). The results of the analysis in the form of teacher and student activity can be seen in Table 5 .

Table 5. ILMIZI Models During E-Learning to Improve PEB-COVID-19

\begin{tabular}{|c|c|c|c|}
\hline No & Syntax & Teacher Activity & Students activity \\
\hline 1 & $\begin{array}{l}\text { Identify } \\
\text { problem }\end{array}$ & $\begin{array}{l}\text { The teacher gives instructions } \\
\text { to students to identify } \\
\text { problems related to COVID-19 } \\
\text { through Whatsapp Group }\end{array}$ & $\begin{array}{l}\text { Students identify environmental } \\
\text { problems related to COVID-19, } \\
\text { then write them in the Whatsapp } \\
\text { group }\end{array}$ \\
\hline 2 & $\begin{array}{l}\text { Limitation } \\
\text { problem }\end{array}$ & $\begin{array}{l}\text { The teacher asks students to } \\
\text { limit existing environmental } \\
\text { problems related to COVID-19 }\end{array}$ & $\begin{array}{l}\text { Students in groups will limit the } \\
\text { problem, and focus on discussing } \\
\text { the problem related to community } \\
\text { behavior in COVID-19 }\end{array}$ \\
\hline 3 & $\begin{array}{l}\text { Make } \\
\text { mind map }\end{array}$ & $\begin{array}{l}\text { The teacher asks students to be } \\
\text { able to make a mind map of } \\
\text { various environmental } \\
\text { activities/behaviors that can be } \\
\text { carried out to prevent the } \\
\text { spread of COVID-19 }\end{array}$ & $\begin{array}{l}\text { Individual students are asked to } \\
\text { make a mind map related to } \\
\text { various factors that cause } \\
\text { community environmental } \\
\text { behavior towards COVID-19 }\end{array}$ \\
\hline 4 & $\begin{array}{l}\text { Interpret } \\
\text { result }\end{array}$ & $\begin{array}{l}\text { The teacher asks students to } \\
\text { interpret the results of the } \\
\text { discussion on Whatsapp group } \\
\text { related to environmental } \\
\text { behavior to prevent COVID-19 }\end{array}$ & $\begin{array}{l}\text { Students interpret the } \\
\text { environmental problems and } \\
\text { discuss in the Whatsapp group, } \\
\text { the discussion must occur in both } \\
\text { directions }\end{array}$ \\
\hline 5 & $\begin{array}{l}\text { Analyze } \\
\text { Result }\end{array}$ & $\begin{array}{l}\text { The teacher asks students to } \\
\text { analyze the results of the } \\
\text { discussion }\end{array}$ & $\begin{array}{l}\text { Students analyze the results of } \\
\text { discussions that have occurred in } \\
\text { the Whatsapp group }\end{array}$ \\
\hline 6 & $\begin{array}{l}\text { Interaction } \\
\text { and } \\
\text { evaluate }\end{array}$ & $\begin{array}{l}\text { The teacher asks students to } \\
\text { upload their mind map work } \\
\text { on Whatsapp Group }\end{array}$ & $\begin{array}{l}\text { Students upload the results of } \\
\text { discussions and mind map works } \\
\text { that have been made to Whatsapp } \\
\text { group }\end{array}$ \\
\hline
\end{tabular}

The results showed that in general students were concerned with their environment. It was based on the PEB-COVID-19 score which was categorized as very high. This is certainly a good thing in education. Even so, there are still some items and indicators that need to be improved so that students can be more concerned about their environment. PEB-COVID-19 is very important for students to have and needs to be improved continuously to be able to adapt to the learning context of COVID-19 outbreaks.

The outbreak of COVID-19 made a change in the learning system from conventional learning in class into e-learning (Erduran, 2020; Wang et al., 2020). This will have an impact on changes in student learning patterns. Besides, 
teachers must prepare various tools related to students' readiness to learn during the COVID-19 outbreak. E-learning can only become effective when it will ensure the interaction among teachers and students. The ILMIZI model can be an option in conducting e-learning. That is because the ILMIZI model makes it possible to implement environmental learning using a variety of social media. One of them uses Whatsapp. Social media is a form of technology implementation in the 21st-century environmental learning (Buzov, 2014; Grosch et al., 2014; Mao, 2014; Reyna et al., 2018; Saltan \& Divarci, 2017). The use of ILMIZI in e-learning has not been implemented yet, but based on the results of the analysis of syntax, teacher activity, and student activity (Table 5) it is very possible to do.

The finding was ILMIZI model helped students learn about their environment by solving different problems around them. It can not only enhance students academic learning but also develop students $21^{\text {st }}$ century skills like problem solving skills. Problem-solving skill is the most important ability demanded by our society which would accelerate students' comprehending knowledge and prepare them to survive future challenges in life (Boholano, 2017; Khoiriyah \& Husamah, 2018; Kivunja, 2014; Koh et al., 2015; Rahman, 2019; Rahmayanti et al., 2020; Sadiqin et al., 2017). So, it can be concluded that this learning model can be a great solution for students in surviving pandemic like COVID-19 and keep up their learning efficiently.

The ILMIZI model can be an alternative because it does not require a lot of complicated learning tools. Besides these ILMIZI syntaxes can be done by teachers and students without having to meet in class. ILMIZI model has the potential to be used in e-learning, in this case, to improve PEB-COVID-19. The task of the teacher can be directed so that students can prevent COVID-19 in the form of implementation of PEB-COVID-19. That is because, in addition to general environmental learning, students also need to be given a variety of environmental concepts that specifically address contextual issues namely COVID-19. Submitting contextual material will make it easier for students to implement a variety of knowledge in the form of behavior (Abiolu, 2019; Harahap et al., 2018; Lai \& Cheng, 2016; Paristiowati et al., 2019; Suleri \& Cavagnaro, 2016).

Learning innovations during COVID-19 are needed to prevent pandemic transmission. Environmental learning has an important role so that students can still maintain their environment to avoid COVID-19. Learning about COVID-19 needs to be improved because it is an interesting current issue for class discussion (Acharya, 2019; Back et al., 2015). That is because the activity of discussing current environmental issues will make students able to think contextually according to the current situation using e-learning. In addition to the use of appropriate learning models, e-learning also requires preparation in terms of facilities so that the environmental learning can still use without obstacles (Chou et al., 2019; Elleithy \& Sobh, 2015; Kew et al., 2018; Mhouti et al., 2017). 


\section{CONCLUSIONS}

Based on the results of the study it can be concluded that the PEB-COVID19 students, in general, are already in the very high category. This indicates that students have tried to prevent COVID-19 in their respective environments. Besides, e-learning was carried out during the COVID-19 pandemic. The ILMIZI model is one of the environmental learning models that can be used during e-learning. This model allows it to be used in e-learning because it does not require much preparation and also enhance the quality of e-learning. Suggestions from this research are to implement ILMIZI in e-learning at various levels of education. Also, various supporting learning tools need to be developed to strengthen the implementation of the ILMIZI model.

\section{ACKNOWLEDGEMENTS}

The authors were sincere appreciation to Aryani Kadarwati Dewi and Nina Wirdianti as a Natural science teacher, for help collected data in Bekasi city and Bandung city, West Java province, Indonesia. Thank for the team in collaboration research who conducted learning innovation during COVID-19.

\section{AUTHOR CONTRIBUTION STATEMENTS}

The author had participated in the research and approved the final version of the manuscript

\section{REFERENCES}

Abiolu, O. A. (2019). Environmental knowledge and behavior of Nigerian youth: An assessment. Applied Environmental Education and Communication, 18(1), 53-67. https://doi.org/10.1080/1533015X.2018.1432431

Acharya, S. (2019). Beyond Learning Outcomes: Impact of Organizational Flexibility on Strategic Performance Measures of Commercial E-Learning Providers. Global Journal of Flexible Systems Management, 20(1), 31-41. https:/ / doi.org/10.1007/s40171-018-0199-3

Al-araibi, A. A. M., Mahrin, M. N. bin, Yusoff, R. C. M., \& Chuprat, S. B. (2019). A model for technological aspect of e-learning readiness in higher education. Education and Information Technologies, 24(2), 1395-1431. https:/ / doi.org/10.1007/s10639-018-9837-9

Alhawiti, M. M., \& Abdelhamid, Y. (2017). A Personalized e-Learning Framework. Journal of Education and E-Learning Research, 4(1), 15-21. https:/ / doi.org/10.20448/journal.509.2017.41.15.21

Back, D. A., Behringer, F., Harms, T., Plener, J., Sostmann, K., \& Peters, H. (2015). Survey of e-learning implementation and faculty support strategies in a cluster of mid-European medical schools. BMC Medical Education, 15(1), 1-9. https:/ / doi.org/10.1186/s12909-015-0420-4

Boholano, H. B. (2017). Smart Social Networking: 21st Century Teaching And Learning Skills. Research in Pedagogy, 7(1), 21-29. https:// doi.org/10.17810/2015.45

Bronfman, N. C., Cisternas, P. C., López-Vázquez, E., De la Maza, C., \& 
Oyanedel, J. C. (2015). Understanding attitudes and pro-environmental behaviors in a chilean community. Sustainability, 7(10), 14133-14152. https:// doi.org/10.3390/su71014133

Buzov, I. (2014). Social network sites as area for students' pro-environmental activities. Procedia - Social and Behavioral Sciences, 152, 1233-1236. https:// doi.org/10.1016/j.sbspro.2014.09.304

Chou, T. L., Wu, J. J., \& Tsai, C. C. (2019). Research Trends and Features of Critical Thinking Studies in E-Learning Environments: A Review. In Journal of Educational Computing Research (Vol. 57, Issue 4). https:// doi.org/10.1177/0735633118774350

Elleithy, K., \& Sobh, T. (2015). New Trends in Networking, Computing, Elearning, Systems Sciences, and Engineering. In K. Elleithy \& T. Sobh (Eds.), Lecture Notes in Electrical Engineering (Vol. 312). Springer International Publishing. https:/ / doi.org/10.1007/978-3-319-06764-3

Erduran, S. (2020). Science Education in the Era of a Pandemic to Education for Understanding and Solving the Covid-19 Crisis? Science E Education. https:/ / doi.org/10.1007/s11191-020-00122-w

Grosch, M., Berger, R., Gidion, G., \& Romeo, M. (2014). Which media services do students use in fact? Results of an international empirical survey. Procedia - Social and Behavioral Sciences, 141, 795-806. https:// doi.org/10.1016/j.sbspro.2014.05.139

Harahap, A., Zuhriyah, A., Rahmayanti, H., \& Nadiroh, N. (2018). Relationship between knowledge of green product, social impact and perceived value with green purchase behavior. E3S Web of Conferences, 74, 4002. https:/ / doi.org/10.1051/e3sconf/20187404002

Ichsan, I. Z. (2019). ILMIZI: Innovation Learning Model for Natural Science and Environmental Learning based on HOTS. International Journal for Educational and Vocational Studies, 1(6), 578-584. https:// doi.org/10.29103/ijevs.v1i6.1640

Ichsan, I. Z., Sigit, D. V., Rahmayanti, H., Purwanto, A., Rosyid, A., Suwandi, T., Ali, A., \& Hermawati, F. M. (2020). Implementasi model pembelajaran ILMIZI dan peningkatan HOTS siswa SD berdasarkan gender pada pembelajaran lingkungan. JIPVA (Jurnal Pendidikan IPA Veteran), 4(1), 1124. https:/ / doi.org/10.31331/jipva.v4i1.1076

Kaiser, F. G., \& Wilson, M. (2004). Goal-directed conservation behavior: the specific composition of a general performance. Personality and Individual Differences, 36(7), 1531-1544. https:/ / doi.org/10.1016/j.paid.2003.06.003

Kartikaningtyas, V., Kusmayadi, T. A., \& Riyadi, R. (2018). The effect of brain based learning with contextual approach viewed from adversity quotient. Journal of Physics: Conference Series, 1022. https://doi.org/10.1088/17426596/1022/1/012014

Kew, S. N., Petsangsri, S., Ratanaolarn, T., \& Tasir, Z. (2018). Examining the motivation level of students in e-learning in higher education institution in Thailand: A case study. Education and Information Technologies, 23(6), 29472967. https:/ / doi.org/10.1007/s10639-018-9753-z 
Khoiriyah, A. J., \& Husamah, H. (2018). Problem-based learning: creative thinking skills, problem-solving skills, and learning outcome of seventh grade students. JPBI (Jurnal Pendidikan Biologi Indonesia), 4(2), 151-160. https:// doi.org/10.22219/jpbi.v4i2.5804

Kivunja, C. (2014). Teaching students to learn and to work well with 21st century skills: unpacking the career and life skills domain of the new learning paradigm. International Journal of Higher Education, 4(1), 1-11. https:// doi.org/10.5430/ijhe.v4n1p1

Koh, J. H. L., Chai, C. S., Wong, B., \& Hong, H. Y. (2015). Design Thinking and 21st Century Skills. In Design Thinking for Education: Conceptions and Applications in Teaching and Learning (pp. 1-131). https:/ / doi.org/10.1007/978-981-287-444-3

Lai, C. K. M., \& Cheng, E. W. L. (2016). Green purchase behavior of undergraduate students in Hong Kong. Social Science Journal, 53(1), 67-76. https:// doi.org/10.1016/j.soscij.2015.11.003

Mao, J. (2014). Social media for learning: A mixed methods study on high school students' technology affordances and perspectives. Computers in Human Behavior, 33(1), 213-223. https:/ / doi.org/10.1016/j.chb.2014.01.002

Mbipom, B., Craw, S., \& Massie, S. (2018). Improving e-learning recommendation by using background knowledge. Expert Systems, November 2017, e12265. https:/ / doi.org/10.1111/exsy.12265

Mhouti, A. El, Erradi, M., \& Nasseh, A. (2018). Using cloud computing services in e-learning process: Benefits and challenges. Education and Information Technologies, 23(2), 893-909. https:/ / doi.org/10.1007/s10639-017-9642-x

Mhouti, A. El, Nasseh, A., Erradi, M., \& Vasquèz, J. M. (2017). Enhancing collaborative learning in Web 2.0-based e-learning systems: A design framework for building collaborative e-learning contents. Education and Information Technologies, 22(5), 2351-2364. https:// doi.org/10.1007/s10639016-9545-2

Nadlifatin, R., Lin, S. C., Rachmaniati, Y. P., Persada, S. F., \& Razif, M. (2016). A pro-environmental reasoned action model for measuring citizens' intentions regarding ecolabel product usage. Sustainability, 8(11), 1-10. https:/ / doi.org/10.3390/su8111165

Paristiowati, M., Hadinugrahaningsih, T., Purwanto, A., \& Karyadi, P. A. (2019). Analysis of students' scientific literacy in contextual-flipped classroom learning on acid-base topic. Journal of Physics: Conference Series, 1156(1), 12026. https:/ / doi.org/10.1088/1742-6596/1156/1/012026

Rahman, M. M. (2019). 21st Century Skill "Problem Solving": Defining the Concept. Asian Journal of Interdisciplinary Research, 2(1), 64-74. https:/ / doi.org/10.34256/ajir1917

Rahmayanti, H., Ichsan, I. Z., Oktaviani, V., Syani, Y., Hadi, W., \& Marhento, G. (2020). Environmental Attitude for Smart City Technology: Need Assessment to Develop Smart Trash in Environmental Education. International Journal of Advanced Science and Technology, 29(3), 8374-8383. Google Scholar 
Reyna, J., Hanham, J., \& Meier, P. (2018). The Internet explosion, digital media principles and implications to communicate effectively in the digital space. E-Learning and Digital Media, 15(1), 36-52. https:// doi.org/10.1177/2042753018754361

Sadiqin, I. K., Santoso, U. T., \& Sholahuddin, A. (2017). Students ' difficulties on science learning with prototype problem-solving based teaching and learning material : a study evaluation of development research. Advances in Social Science, Education and Humanities Research, 100, 279-282. https:// doi.org/10.2991/seadric-17.2017.58

Saltan, F., \& Divarci, O. F. (2017). Using Blogs to Improve Elementary School Students' Environmental Literacy in Science Class. European Journal of Educational Research, 6(3), 347-355. https:/ / doi.org/10.12973/eu-jer.6.3.347

Sigit, D. V., Miarsyah, M., Komala, R., Suryanda, A., Ichsan, I. Z., \& Fadrikal, R. (2020). EECN: Analysis, potency, benefit for students knowledge and attitude to conserve mangroves and coral reefs. International Journal of Instruction, 13(1), 125-138. https:/ / doi.org/10.29333/iji.2020.1318a

Sintema, E. J. (2020). Effect of COVID-19 on the Performance of Grade 12 Students: Implications for STEM Education. Eurasia Journal of Mathematics, Science and Technology Education, 16(7), 1-6. https:// doi.org/10.29333/ ejmste/7893

Suleri, J., \& Cavagnaro, E. (2016). Promoting pro-environmental printing behavior: The role of ICT barriers and sustainable values. International Journal of Education and Development Using Information and Communication Technology, 12(2), 158-174. https://doi.org/DOI: 10.1016/j.ijpharm.2004.11.024

Teo, T. S. H., Kim, S. L., \& Jiang, L. (2018). E-Learning Implementation in South Korea: Integrating Effectiveness and Legitimacy Perspectives. Information Systems Frontiers. https:/ / doi.org/10.1007/s10796-018-9874-3

Tian, S., Hu, N., Lou, J., Chen, K., Kang, X., Xiang, Z., Chen, H., Wang, D., Liu, N., Liu, D., Chen, G., Zhang, Y., Li, D., Li, J., Lian, H., Niu, S., Zhang, L., \& Zhang, J. (2020). Characteristics of COVID-19 infection in Beijing. Journal of Infection, 80(4), 401-406. https:/ / doi.org/10.1016/j.jinf.2020.02.018

Voight, A. M., Geller, J. D., \& Nation, M. (2014). Contextualizing the "Behavior Gap": Student Prosocial Behavior and Racial Composition in Urban Middle Schools. Journal of Early Adolescence, 34(2), 157-177. https:// doi.org/10.1177/0272431613482043

Wang, Y., Di, Y., Ye, J., \& Wei, W. (2020). Study on the public psychological states and its related factors during the outbreak of coronavirus disease 2019 (COVID-19) in some regions of China. Psychology, Health $\mathcal{E}$ Medicine, 8506, 1-10. https:// doi.org/10.1080/13548506.2020.1746817

Zhou, G., Chen, S., \& Chen, Z. (2020). Back to the spring of Wuhan: facts and hope of COVID-19 outbreak. Frontiers of Medicine, 1-4. https:/ / doi.org/10.1007/s11684-020-0758-9 


\section{Copyright Holder :}

(C) Ichsan, I., Rahmayanti, H., Purwanto, A., Sigit, V., \& Rahman, Md. (2020)

First Publication Right :

(C) Jurnal Iqra' : Kajian Ilmu Pendidikan

This article is under:

(ㄷ) (1) (2) 